\title{
Gazette
}

\section{Committees of APSA}

\section{COUNCIL COMMITTEES}

\section{Administrative Committee}

The administrative committee consists of the president, president-elect, treasurer, and four other council members whose main duties include preparing agendas for council meetings and annual business meetings and acting on behalf of the council to dispose of policy issues deemed of insufficient weight to require decisions by the council.

Term expiring August 31, 2013

John H. Aldrich, Duke University

Jonathan Benjamin-Alvarado, University of Nebraska, Omaha

Nancy J. Hirschmann, University of Pennsylvania

Taeku Lee, University of California, Berkeley

Jane Mansbridge, Harvard University, Chair

Todd C. Shaw, University of South Carolina

Kathleen Thelen, Massachusetts Institute of Technology

\section{Audit Committee}

The audit committee supervises the conduct of APSA's audit and oversee that adequate internal controls exist for the Association's accounting and finance. The audit committee is comprised of three members: two from the council and one from the trust and development board of trustees. Members and the chair are named by the president with the advice and consent of the council.

$$
\begin{aligned}
& \text { Term expiring August 31, } 2013 \\
& \text { Gretchen G. Casper, Pennsylvania } \\
& \text { State University, Chair } \\
& \text { Charles W. Gossett, California State } \\
& \text { University, Sacramento } \\
& \text { Paul Gronke, Reed College }
\end{aligned}
$$

\section{Committee on Elections}

The APSA Council Committee on Elections supervises the conduct of APSA's elections. Three members are appointed after the election from among newly elected and continuing council members.
Term expiring August 31, 2013

Brian F. Crisp, Washington University, St. Louis

Stephen M. Walt, Harvard University, Chair

Angelia Ruth Wilson, University of Manchester

\section{Council Finance Committee}

The finance committee examines and interprets the trends in APSA finances and oversees patterns of revenues and expenditures relative to budget.

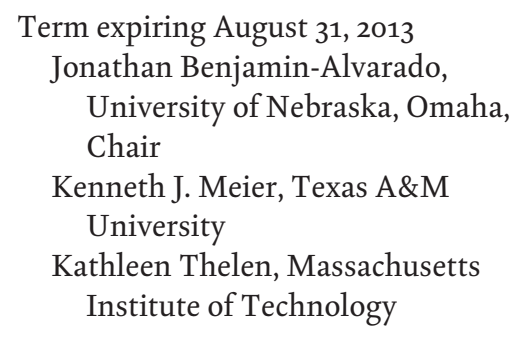

\section{Committee on Rules}

The APSA Council Committee on Rules reviews APSA's by-laws and rules of procedure for governing the conduct of the annual business meeting and proposes revisions as they are deemed necessary.

Term expiring August 31, 2013

Ange-Marie Hancock, University of Southern California

David A. Lake, University of California, San Diego, Chair

Joanne Miller, University of Minnesota

\section{STANDING COMMITTEES}

\section{Africa Project Steering Committee}

Term expiring August 31, 2014

Catherine Boone, University of Texas, Austin

Michael A. Brintnall, American Political Science Association

Mamadou Diouf, Columbia University

Ronald Kassimir, New School University

Ira Katznelson, Columbia University, Chair

Leonard Wantchekon, New York University

\section{Committee on Annual Meetings}

The Committee on the Annual Meeting is designed to oversee the practices and policies of the APSA Annual Meeting.

Term expiring August 31, 2013

Elisabeth R. Gerber, University of Michigan

Frederick P. Lewis, University of Massachusetts-Lowell

Term expiring August 31, 2014

Nancy Bermeo, Oxford University, Chair

Janelle Wong, University of Maryland

Term expiring August 31, 2015

Maryann Barakso, University of Massachusetts, Amherst

Eric L. McDaniel, University of Texas, Austin

\section{Committee on the Status of Asian Pacific Americans in the Profession}

The Committee on the Status of Asian Pacific Americans in the Profession develops and promotes activities concerning the professional development of Asian American and Pacific Islander political scientists.

Term expiring August 31, 2013

Claire Jean Kim, University of California, Irvine, Chair

Paul Y. Watanabe, University of Massachusetts, Boston

Term expiring August 31, 2014

Wendy K. Tam Cho, University of Illinois at Urbana-Champaign, Chair

Sarah Song, University of California, Berkeley

Term expiring August 31, 2015

Kira Sanbonmatsu, Rutgers University

Lee Trepanier, Saginaw Valley State University

\section{Committee on the Status of Blacks} in the Profession

The Committee on the Status of Blacks in the Profession develops and promotes activities concerning the professional 
development of African Americans within the discipline.

Term expiring August 31, 2013

Russell Benjamin, Northeastern Illinois University

Ange-Marie Hancock, University of Southern California

Term expiring August 31, 2014

Christopher S. Parker, University of Washington

Melynda J. Price, University of Kentucky, Chair

Term expiring August 31, 2015

Andra N. Gillespie, Emory University

B. D'Andra Orey, Jackson State University

\section{Centennial Center Advisory Board}

The Centennial Center Advisory Board guides practices of the Centennial Center, oversees funds for Center activities, and makes final decisions on awarding of Centennial Center scholarships and grants.

Term expiring August 31, 2013

Nancy J. Hirschmann, University of Pennsylvania, Chair

Michael J. Laver, New York University

Laura Stoker, University of California, Berkeley

Term expiring August 31, 2014

Alice M. Jackson, Morgan State University

Stathis N. Kalyvas, Yale University

Daniel N. Posner, Massachusetts Institute of Technology

Term expiring August 31, 2015

Kristin Bumiller, Amherst College

Colleen J. Shogan, Congressional Research Service

Charles A. Stevenson, Johns Hopkins SAIS

\section{Committee on Civic Education}

The Committee on Civic Education focuses on the contributions that higher education, and political sciences in higher education institutions, are making or could make to enhance the quantity and quality of civic engagement among young Americans.

Term expiring August 31, 2013

Archon Fung, Harvard University

Elizabeth Theiss Smith, University of South Dakota, Chair

Term expiring August 31, 2014

Scott Abernathy, University of Minnesota
Term expiring August 31, 2015

Els de Graauw, CUNY-Baruch College

Peter Levine, Tufts University

\section{Committee on Departmental Services}

The Committee on Departmental Services oversees APSA's Departmental Services Program (DSP) which provides a forum for political science departments large and small to address common issues, and plan and develop publications and services for chairs, faculty, and students. The program, overseen by the Departmental Services Committee, supports political science teaching, scholarship, and service, and provides resources for department chairs.

Term expiring August 31, 2013

Brooke A. Ackerly, Vanderbilt

Elizabeth Theiss-Morse, University of Nebraska, Lincoln, Chair

Term expiring August 31, 2014 James Jennings, Tufts University Patrick J. Sellers, Davidson College

Term expiring August 31, 2015 Richard C. Fording, University of Alabama, Tuscaloosa

C. Danielle Vinson, Furman University

\section{Development Committee}

This committee proposes development goals and policies to the Counci and oversees their eventual implementation; and has oversight of APSA Awards.

Term expiring August 31, 2013

Jennifer L. Hochschild, Harvard University

Michael B. Preston, University of Southern California

Term expiring August 31, 2014

Mark Q. Sawyer, University of California, Los Angeles

Sidney Tarrow, Cornell University

Term expiring August 31, 2015

Virginia Sapiro, Boston University, Chair

Elliot E. Slotnick, Ohio State University

\section{Executive Director Search Committee}

Term expiring August 31, 2013

Michelle D. Deardorff, Jackson State University

Henry Farrell, George Washington University

Stathis N. Kalyvas, Yale University

Margaret Levi, University of Washington, Seattle, Chair
Walter R. Mebane, Jr., University of Michigan

Julie L. Novkov, SUNY, University at Albany

Kay Lehman Schlozman, Boston College

Charles Anthony Smith, University of California, Irvine

\section{Committee on Professional Ethics, Rights, and Freedoms}

The committee's responsibility is to protect the rights of political scientists and ensure that the ethical policies of the association are followed.

Term expiring August 31, 2013

Michael Lienesch, University of North Carolina, Chapel Hill

Marion Smiley, Brandeis University

Term expiring August 31, 2014

Sarah Birch, University of Essex

Christian Davenport, University of Notre Dame

Term expiring August 31, 2015

Yvette M. Alex-Assensoh, Indiana University, Bloomington, Chair

Kenneth Sherrill, CUNY-Hunter College

\section{Committee on International Political}

\section{Science}

This committee recommends policy to the APSA council regarding internationalization of the association, develops relationships between American political science and political science in other nations, and oversees APSA's relationship with IPSA and other non-U.S. national and international associations.

Term expiring August 31, 2013

Terri E. Givens, University of Texas, Austin

Michael R. Tomz, Stanford University

Term expiring August 31, 2014

Michael Bratton, Michigan State University

Gail McElroy, Trinity College, Dublin, Chair

Term expiring August 31, 2015

Thomas Risse, Freie Universität Berlin

Aili Mari Tripp, University of Wisconsin, Madison

\section{Committee on the Status of Latinos y Latinas in the Profession}

The Committee on the Status of Latinos y Latinas in the Profession develops and promotes activities concerning 
the professional development of Latinos within the discipline.

Term expiring August 31, 2013

Irasema Coronado, University of

Texas, El Paso, Chair

Louis DeSipio, University of California, Irvine

Term expiring August 31, 2014

Jose E. Cruz, SUNY, University at Albany

Sonia R. Garcia, St. Mary's University

Term expiring August 31, 2015

Marisa Abrajano, University of California, San Diego

Ricardo Ramirez, University of Notre Dame

Committee on the Status of Lesbians, Gays, Bisexuals, and the Transgendered

This committee assesses the status of gay, lesbian, bisexual, and transgendered (LBBT) scholars in the profession, advances the research on LGBT issues, develops curriculum materials, and works to ensure tolerance toward LGBT political scientists.

Term expiring August 31, 2013

Roddrick Colvin, John Jay College

Beth Kiyoko Jamieson, The Fund for New Jersey

Term expiring August 31, 2014

Steve Sanders, University of Michigan

Sahar Shafqat, St. Mary's College of Maryland

Term expiring August 31, 2015

Heath Fogg Davis, Temple University

Charles Anthony Smith, University of California, Irvine, Chair

\section{Ad Hoc Committee on Membership Communications}

The committee is charged is to look broadly at ways APSA communicates with its members and with the global political science scholarly community, and to advise APSA Staff.

Term expiring August 31, 2013

Barry C. Burden, University of Wisconsin, Madison

Kerstin Hamann, University of Central Florida

Pippa Norris, Harvard University

John M. Sides, George Washington University

Mark Zachary Taylor, Georgia Institute of Technology

Irene $\mathrm{S}$. Wu, Federal Communications Commisssion
Middle East Workshop Steering

\section{Committee}

Term expiring August 31, 2014

Mustapha K. Al Sayyid, American University in Cairo

Lisa Anderson, American University in Cairo, Chair

Nancy Bermeo, Oxford University

Henry E. Brady, University of California, Berkeley

Michael A. Brintnall, American Political Science Association

Joseph G. Jabbra, Lebanese American University

Amaney Jamal, Princeton University

\section{MFP Grantee Selection Committee}

Term expiring August 31, 2013

Wendy K. Tam Cho, University of Illinois at Urbana-Champaign

Sonia R. Garcia, St. Mary's University

B. D'Andra Orey, Jackson State University

\section{Nominating Committee}

Term expiring August 31, 2013

Fredrick C. Harris, Columbia University

Jeffrey B. Lewis, University of California, Los Angeles

Melanie Frances Manion, University of Wisconsin, Madison

Term expiring August 31, 2014

Kristi Andersen, Syracuse University, Chair

Jeffrey Herbst, Colgate University

Michael A. Jones-Correa, Cornell University

\section{Publications Committee}

The committee oversees and coordinates existing APSA publications, leads in setting standards for APSA journals and other publications, explores possible relationships with political science journals not sponsored by the Association, and develops proposals for new publications, when appropriate.

Term expiring August 31, 2013

Albert Peter Weale, University College London

Lisa Wedeen, University of Chicago

Term expiring August 31, 2014

Jan E. Leighley, American University

Kaare Strom, University of California, San Diego, Chair

Term expiring August 31, 2015

Darren Davis, University of Notre Dame
Simon D. Jackman, Stanford University

Term expiring June 30, 2016

Robert J-P. Hauck, APSA

Jeffrey C. Isaac, Indiana University, Bloomington

John Ishiyama, University of North Texas

\section{Publications Planning Committee}

The charge to the Publications Planning Committee is to look broadly at the needs, opportunities and issues for the future of scholarly publications and communications of the association, and to make recommendations for new initiatives or changes in approach. In conducting its analysis, the committee will want to consider the evolving technologies and formats for electronic media and open access, the formats and editorial arrangements for the existing publications and communications of the Association, including standing journals, eNewsletters, organized section journals and newsletters, ideas for eJournals, and the future prospects for the editorial arrangement and structure for PS: Political Science and Politics.

The committee should also consider how the APSA scholarly journals are balanced regarding the needs of scholarly production, research audiences and teaching, junior faculty and emerging scholars, association members, press and policy makers, and the attentive public.

Term expiring September 30, 2013

Larry M. Bartels, Vanderbilt University

Simone Chambers, University of Toronto

Derrick L. Cogburn, American University

Eric Crahan, Oxford University Press

Yoshiko M. Herrera, University of Wisconsin, Madison

Jennifer L. Hochschild, Harvard University, Chair

Macartan Humphreys, Columbia University

Karen M. Kedrowski, Winthrop University

Marc Lynch, George Washington University

Rahsaan Maxwell, University of Massachusetts, Amherst

Ricardo Ramirez, University of Notre Dame

Kaare Strom, University of California, San Diego 


\section{Committee on Organized Sections}

The role of the Committee is to help Organized Sections carry out their work and to oversee the balance between Sections and APSA as a whole. As Section issues have become more routinized we expect that this Committee can function as a board that meets by email and phone to address issues of compliance with APSA section procedures.

Term expiring August 31, 2013

Erik S. Herron, University of Kansas, Chair

Pamela Stricker, California State University, San Marcos

Term expiring August 31, 2014

Steven P. Erie, University of California, San Diego

Nanette S. Levinson, American University

Term expiring August 31, 2015

Diane J. Heith, St. John's University

Evelyn M. Simien, University of Connecticut

\section{Siting and Engagement Committee}

The committee addresses the application of APSA siting policy for the APSA annual meeting, Teaching and Learning Conference, and any other major APSA meetings, and once a site has been selected by APSA, plans for a program of public engagement in the community.

\section{Term expiring August 31, 2013 \\ Karen Mossberger, University of Illinois, Chicago \\ Gary M. Segura, Stanford University \\ Steven Rathgeb Smith, Georgetown University \\ Term expiring August 31, 2014 \\ Marion Orr, Brown University \\ Amalia Pallares, University of Illinois, Chicago \\ Clyde Wilcox, Georgetown University, Chair}

Term expiring August 31, 2015

Andrew L. Aoki, Augsburg College

Michael J. Bosia, St. Michael's College

Laura Stoker, University of California, Berkeley

\section{Trust and Development Board}

The APSA Trust and Development Board is charged by the APSA Constitution to oversee association assets and reports on association investment practices.
Term expiring August 31, 2013

Jonathan Benjamin-Alvarado, University of Nebraska, Omaha, Chair

Term expiring December 31, 2013

John A. Garcia, University of Arizona

Dale Rogers Marshall, Wheaton College

Term expiring December 31, 2014

Frances McCall Rosenbluth, Yale University

Peter J. Steinberger, Reed College

Term expiring December 31, 2015

Charles W. Gossett, California State University, Sacramento

Lyn Ragsdale, Rice University

\section{Committee on Teaching and Learning}

The APSA Committee on Teaching and Learning in Political Science develops and promotes activities within the Association and the political science community regarding political science and the practices and policies of higher education, including undergraduate, graduate, professional and life-long education. The Committee also advises the APSA Council on the practices and policy for the annual Teaching and Learning Conference.

Term expiring August 31, 2013

Craig Leonard Brians, Virginia Tech

Emily Hauptmann, Western Michigan University

Term expiring August 31, 2014

Michelle D. Deardorff, Jackson State University, Chair

Peter L. Francia, East Carolina University

Term expiring August 31, 2015

Jeffrey L. Bernstein, Eastern Michigan University

Kathleen A. Mahoney-Norris, Air Command and Staff College

\section{Teaching Conference Organizers}

The program committee for the Conference on Teaching and Learning in Political Science sets the themes for the meeting and oversees the formation of the conference tracks.

Term expiring April 30, 2013

Michelle D. Deardorff, Jackson State University

Tressa E. Tabares, American River College

Candace C. Young, Truman State University, Chair
Term expiring April 30, 2014

Victor Asal, SUNY, University at Albany

Agnieszka Paczynska, George Mason University

Boris E. Ricks, California State University, Northridge

\section{Committee on the Status of Women in the Profession}

The committee monitors and reports on the status of women in the profession, advances research on women and on issues of concern to women, develops and assesses curriculum materials, and works to ensure fair and equal treatment of women in the profession.

Term expiring August 31, 2013

Jane H. Bayes, California State University, Northridge

Pippa Norris, Harvard University

Term expiring August 31, 2014

Nikol G. Alexander-Floyd, Rutgers University, Chair

Miki Caul Kittilson, Arizona State University

Term expiring August 31, 2015

Lilian A. Barria, Eastern Illinois University

Laurel Elder, Hartwick College

\section{AWARD COMMITTEES}

\section{Gabriel A. Almond Award Committee}

The Gabriel A. Almond Award is for the best doctoral dissertation in the field of comparative politics.

Term expiring August 31, 2013

Liesbet Hooghe, University of North Carolina, Chapel Hill and VU University Amsterdam,

Dan Slater, University of Chicago

Erik M. Wibbels, Duke University

\section{William Anderson Award Committee}

The William Anderson Award is for the best doctoral dissertation in the field of state and local government, federalism or intergovernmental relations.

Term expiring August 31, 2013

Barbara Allen, Carleton College, Chair

Tulia G. Falleti, University of Pennsylvania

Paul L. Posner, George Mason University

\section{Ralph J. Bunche Award Committee}

The Ralph J. Bunche Award is for the best scholarly work in political science 
published in the previous calendar year which explores the phenomenon of ethnic and cultural pluralism.

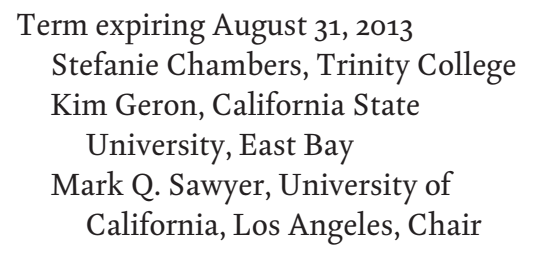

\section{Franklin L. Burdette Pi Sigma Alpha Award Committee}

The Franklin L. Burdette Pi Sigma Alpha Award is for the best paper presented at the previous annual meeting.

Term expiring August 31, 2013

Sheri Berman, Barnard College-

Columbia University

Alan Gerber, Yale University, Chair

Bernard N. Grofman, University of California, Irvine

\section{Edward S. Corwin Award Committee}

The Edward S. Corwin Award is for the best doctoral dissertation in the field of public law.

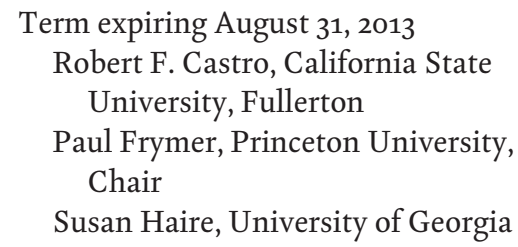

\section{Heinz Eulau Award Committee}

The Heinz Eulau Award is for the best article published in the APSR and Perspectives on Politics during the previous calendar year. Two Eulau Awards are made, one for each journal. Committee members are asked to help make the selection from one journal or the other, and the chair is asked to participate in both decisions.

Term expiring August 31, 2013

Jonathan Bendor, Stanford University

Jose Antonio Cheibub, University of Illinois at Urbana-Champaign

John S. Dryzek, Australian National University

Suzanne Mettler, Cornell University, Chair

Valeria Sinclair-Chapman, University of Rochester

\section{John Gaus Lecture Committee}

The John Gaus Lecture honors the recipient's lifetime of exemplary scholarship in the joint tradition of political science and public administration and to recognize achievement and encourage scholarship in public administration.

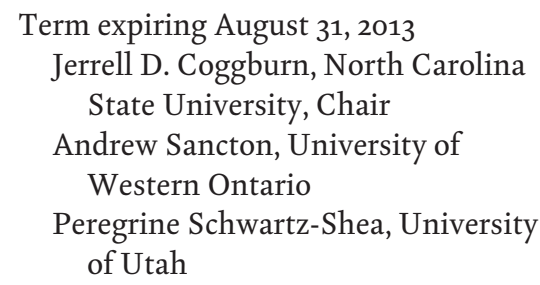

\section{Frank J. Goodnow Award}

The Goodnow Award recognizes distinguished service to the profession and the association, not necessarily a career of scholarship. This service may be by individuals, groups, and public and private organizations who have played a role in the development of the political science profession and the building of American Political Science Association.

\section{Term expiring August 31, 2013 \\ Erik S. Herron, National Science Foundation \\ Michael B. Preston, University of Southern California \\ Elizabeth Theiss-Morse, University of Nebraska, Lincoln, Chair}

\section{Hubert H. Humphrey Award Committee}

The Hubert H. Humphrey Award is in recognition of notable public service by a political scientists.

Term expiring August 31, 2013

Danielle Allen, Institute for Advanced Study

Mary Hawkesworth, Rutgers

University, Chair

Darrell M. West, The Brookings Institution

\section{Gladys M. Kammerer Award Committee}

The Gladys M. Kammerer Award is for the best political science publication in the previous calendar year in the field of US national policy.

$$
\begin{aligned}
& \text { Term expiring August 31, } 2013 \\
& \text { Lonna Rae Atkeson, University of } \\
& \text { New Mexico } \\
& \text { Elisabeth R. Gerber, University of } \\
& \text { Michigan, Chair } \\
& \text { Kent E. Portney, Tufts University }
\end{aligned}
$$

\section{Harold D. Lasswell Award Committee}

The Harold D. Lasswell Award is for the best doctoral dissertation in the field of policy studies. The award is supported by the Policy Studies Organization and the APSA Organized Section on Public Policy.

Term expiring August 31, 2013

David E. Campbell, University of Notre Dame

Sheldon Kamieniecki, University of California, Santa Cruz, Chair

Mara Sidney, Rutgers University, Newark

\section{Benjamin E. Lippincott Award Committee}

The Benjamin E. Lippincott is to recognize a work of exceptional quality by a living political theorist that is considered significant after a time span of at least 15 years since the original date of publication. Supported by the University of Minnesota. The award is biennnial.

Term expiring August 31, 2013

Jeffrey Abramson, University of Texas, Austin, Chair

Jill Frank, University of South Carolina

Michael Neblo, Ohio State University

\section{Carey Mcwilliams Award Committee}

The Carey McWilliams Award is to honor a major journalistic contribution to our understanding of politics.

Term expiring August 31, 2013

Victoria Maria DeFrancesco Soto, University of Texas, Austin

Forrest Maltzman, George Washington University

Susan McWilliams, Pomona College, Chair

\section{Charles E. Merriam Award Committee}

The Charles E. Merriam Award is given to a person whose published work and career represents a significant contribution to the art of government through application of social science research. The award is biennial.

\section{Term expiring August 31, 2013 \\ Linda L. Fowler, Dartmouth College \\ Amy Gutmann, University of Pennsylvania, Chair \\ John Mark Hansen, University of Chicago}

\section{Ithiel Desola Pool Lecture Committee}

The Ithiel deSola Pool is given to a scholar selected to explore the implications of research on issues of politics in a global society, evoking the broad range of scholarship pursued by Ithiel deSola Pool. 
Term expiring August 31, 2013

James N. Druckman, Northwestern University, Chair

Stephen J. Farnsworth, University of Mary Washington

Melissa Nobles, Massachusetts Institute of Technology

\section{Helen Dwight Reid Award Committee}

The Helen Dwight Reid Award is for the best doctoral dissertation in the field of international relations, law and politics.

Term expiring August 31, 2013

Virginia Haufler, University of Maryland

Shaheen Mozaffar, Bridgewater State University

Beth A. Simmons, Harvard University, Chair

\section{E. E. Schattschneider Award Committee}

The E. E. Schattschneider Award is for the best doctoral dissertation in the field of American government.

Term expiring August 31, 2013

Brandice Canes-Wrone, Princeton University, Chair

Donald P. Green, Columbia University

Jose Angel Gutierrez, University of Texas-Arlington

\section{Victoria Schuck Award Committee}

The Victoria Schuck Award is for the best book published in the previous calendar year on women and politics.

Term expiring August 31, 2013

Sharon Denise Austin, University of Florida

Lisa J. Disch, University of Michigan

S. Laurel Weldon, Purdue University, Chair

\section{Leo Strauss Award Committee}

The Leo Strauss Award is for the best doctoral dissertation in the field of political philosophy.

Term expiring August 31, 2013

Jason Frank, Cornell University

Stephen G. Salkever, Bryn Mawr College, Chair

Mark E. Warren, University of British Columbia

\section{APSA Distinguished Teaching Award}

The APSA Distinguished Teaching Award honor's outstanding contributions to undergraduate and graduate teaching of political science at two- and four-year, and graduate level, institutions. It may recognize a series of contributions spanning several years or an entire career, or a single project of exceptional impact.

Term expiring August 31, 2013

Jay Barth, Hendrix College

Mary Fainsod Katzenstein, Cornell

University, Chair

Richard G. Niemi, University of Rochester

\section{Leonard D. White Award Committee}

The Leonard D. White Award is for the best doctoral dissertation in the field of public administration.

Term expiring August 31, 2013

Barbara C. Burrell, Northern Illinois University

Stefanie A. Lindquist, University of Texas, Austin, Chair

Steven Maynard-Moody, University of Kansas

\section{Woodrow Wilson Foundation Award Committee}

The Woodrow Wilson Foundation Award is for the best book published in the United States during the previous calendar year on government, politics, or international affairs. The award is supported by the Woodrow Wilson Foundation.

Term expiring August 31, 2013

Evelyne Huber, University of North Carolina, Chapel Hill

Gary C. Jacobson, University of California, San Diego, Chair

Ronald J. Schmidt, Sr., California State University, Long Beach

\section{EDITORIAL BOARDS}

American Political Science Review Editors

Marijke Breuning, University of North Texas

Steven Forde, University of North Texas

John Ishiyama, University of North Texas - Lead Editor

Valerie Martinez Ebers, University of North Texas

\section{APSR EDITORIAL BOARD}

Term expiring June 30, 2016

Kees Aarts, University of Twente

Lawrence Baum, Ohio State University

Cristina Beltran, New York University
Kenneth R. Benoit, London School of Economics

Carles Boix, Princeton University

Catherine Boone, University of Texas, Austin

Shaun Bowler, University of California, Riverside

Janet M. Box-Steffensmeier, Ohio State University

James W. Ceaser, University of Virginia

Kanchan Chandra, New York University

Wendy K. Tam Cho, University of Illinois at Urbana-Champaign

Nazli Choucri, Massachusetts Institute of Technology

Susan E. Clarke, University of Colorado, Boulder

Cathy J. Cohen, University of Chicago

Christian Davenport, University of Notre Dame

Adeed Dawisha, Miami University

Kris Deschouwer, Vrije Universiteit Brussel

Mary G. Dietz, Northwestern University

Lawrence C. Dodd, University of Florida

Roxanne L. Euben, Wellesley College

Francis Fukuyama, Stanford University

Sumit Ganguly, Indiana University

Elisabeth R. Gerber, University of Michigan

Nils Petter Gleditsch, International Peace Research Institute

Kerstin Hamann, University of Central Florida

Mary Hawkesworth, Rutgers University

Rodney E. Hero, University of California, Berkeley

Vicki L. Hesli, University of Iowa

H. N. Hirsch, Oberlin College

William G. Howell, University of Chicago

Leonie Huddy, SUNY, Stony Brook

Valerie M. Hudson, Texas A\&M University

Vincent L. Hutchings, University of Michigan

Patrick James, University of Southern California

Jane Y. Junn, University of Southern California

Timothy V. Kaufman-Osborn, Whitman College

Gary King, Harvard University

Joy Langston, CIDE 
Jack S. Levy, Rutgers University

Stephen Macedo, Princeton University

Daniel J. Mahoney, Assumption College

Richard E. Matland, Loyola University, Chicago

Kenneth J. Meier, Texas A\&M University

Andrey Y. Melville, Moscow State Institute of International Relations

Alex Mintz, Interdisciplinary Center

Sara McLaughlin Mitchell, University of Iowa

Shaheen Mozaffar, Bridgewater State University

Terry Nardin, National University of Singapore

Cary J. Nederman, Texas A\&M University

Mary P. Nichols, Baylor University

Julie L. Novkov, SUNY, University at Albany

Mustapha Kamal Pasha, University of Aberdeen

Dianne M. Pinderhughes, University of Notre Dame

Todd Sandler, University of Texas at Dallas

Andreas Schedler, Centro de Investigación y Docencia Económicas

Kay Lehman Schlozman, Boston College

Ronald J. Schmidt, Sr., California State University, Long Beach

Norman Schofield, Washington University

Gary M. Segura, Stanford University

Reginald S. Sheehan, Michigan State University

Olga V. Shvetsova, Binghamton University, SUNY

Kathryn Sikkink, University of Minnesota, Minneapolis

Beth A. Simmons, Harvard University

Etel L. Solingen, University of California, Irvine

Manfred B. Steger, University of Hawaii, Manoa

Alexander C. Tan, University of Canterbury
Katherine Tate, University of California, Irvine

Nicolas van de Walle, Cornell University

Craig Volden, University of Virginia

Barbara F. Walter, University of California, San Diego

Carol S. Weissert, Florida State University

Linda M.G. Zerilli, University of Chicago

Christopher Zorn, Pennsylvania State University

\section{Perspectives on Politics}

Editor: Jeffrey C. Isaac, Indiana University

Term expiring May 31, 2013

Edwina Barvosa, University of California, Santa Barbara

Richard M. Battistoni, Providence College

Daniel W. Drezner, Tufts University

Henry Farrell, George Washington University

Page Fortna, Columbia University

Marc Morjé Howard, Georgetown University

Mala N. Htun, University of New Mexico

Bryan D. Jones, University of Texas, Austin

Stathis N. Kalyvas, Yale University

Mary Fainsod Katzenstein, Cornell University

Timothy V. Kaufman-Osborn, Whitman College

Elizabeth Markovits, Mount Holyoke

Melissa Nobles, Massachusetts Institute of Technology

Paul Pierson, University of California, Berkeley

James C. Scott, Yale University

Dara Z. Strolovitch, University of Minnesota, Twin Cities

Lisa Wedeen, University of Chicago

\section{PS: Political Science and Politics}

Editor: Robert J-P Hauck, APSA

Term expiring August 31, 2013 Jennifer Leigh Disney, Winthrop University
Emily R. Gill, Bradley University

Susan Hekman, University of Texas, Arlington, Chair

William L. Niemi, Western State College of Colorado

Daniel N. Posner, Massachusetts Institute of Technology

Term expiring August 31, 2014

Matthew R. Cleary, Syracuse University

Diana Evans, Trinity College

Heath Fogg Davis, Temple University

Liesbet Hooghe, University of North Carolina, Chapel Hill and VU University Amsterdam

Ronald J. Schmidt, Sr., California State University, Long Beach

Term expiring August 31, 2015

Rodolfo Espino, III, Arizona State University

Matthew Hindman, Arizona State University

Kathryn C. Lavelle, Case Western Reserve University

Lori Marso, Union College

Rose McDermott, Brown University

\section{APSA Liaisons to Affiliated} Organizations

Elisabeth R. Gerber, University of Michigan

Liaison to Consortium of Social Science Associations (COSSA), 2012-2013

James McAllister, Williams College

Liaison to U.S. Dept of State Advisory Committee on Historical, 2010-2013

Jennifer L. Merolla, Claremont Graduate University

Liaison to American Association for the Advancement of Sciences (AAAS), 2012-2015

Joshua A. Tucker, New York University

Liaison to Association for Slavic, East European, and Eurasian Studies, 2011-2014

Richard M. Valelly, Swarthmore College

Liaison to American Council of Learned Societies (ACLS), 2011-2014 